\title{
A influência do fator de crescimento endotelial vascular na maturação "in vitro" de células dendríticas derivadas de monócitos
}

\author{
LUCIANA CAVALHEIRO MARTI
}

Tese apresentada ao Programa de Pós-Graduação Interunidades em Biotecnologia USP/Instituto Butantan/IPT para obtenção do Título de Doutor em Biotecnologia.

Área de concentração: Biotecnologia

Orientador: Prof. Dr. Carlos Alberto Moreira Filho

São Paulo

2008 


\section{DEDICATÓRIA}

Para meu esposo Eugênio por estes anos de paciência, compreensão, tolerância e amor. 


\section{RESUMO}

Marti LC. A influência do fator de crescimento endotelial vascular na maturação "in vitro" de células dendríticas derivadas de monócitos [Tese]. São Paulo: Instituto de Ciências Biomédicas da Universidade de São Paulo; 2008.

Células dendríticas (DCs) são as responsáveis por orquestrar a resposta imunológica adaptativa através da estimulação de células T. Por isso, a maturação anormal destas pode interferir no resultado final da resposta imune. Neste estudo, analisaram-se os efeitos causados pelo fator de crescimento endotelial vascular (VEGF) na maturação de DCs. Nas DCs maturadas em presença de VEGF, por citoquímica, constatou-se alterações morfológicas, como número reduzido de dendritos e citoplasma basofílico; a análise de expressão gênica global por microarranjos de DNA mostrou grande variação da expressão de genes relacionados com adesão celular e citoesqueleto. Na avaliação funcional verificou-se redução da capacidade das DCs de ativar linfócitos. Juntos esses resultados sugerem que células expostas ao VEGF seriam menos especializadas. A compreensão do impacto do VEGF em mecanismos de maturação celular contribui para o entendimento da supressão imunológica nos tumores que secretam VEGF.

Palavras-chave: Células dendríticas; Resposta imunológica; VEGF; Maturação; Supressão. 


\begin{abstract}
Marti LC. The influence of vascular endothelial growth factor in monocyte derived dendritic cell maturation "in vitro" [Tese]. São Paulo: Instituto de Ciências Biomédicas da Universidade de São Paulo; 2008.

Dendritic cells (DCs) are in charge of orchestrating the adaptive immune response through T cells activation. Thus, DCs inadequate maturation interferes in the outcome of the immune response. In this study, were analyzed the effects of vascular endothelial growth factor (VEGF) on DCs maturation. DCs matured in the presence of VEGF, showed morphologic alterations such as reduced number of dendrites and basophilic cytoplasm by cytochemistry. Global gene expression assessed by DNA microarrays demonstrated broad variation in the expression of cell adhesion and cytoskeleton regulation-related genes. Functional studies detected the reduced capacity of VEGFexposed DCs in the activation of lymphocytes. All together these results suggest that cells exposed to VEGF are less differentiated, a possible mechanism involved in the immune suppression caused by VEGF secreting tumors.
\end{abstract}

Key words: Dendritic cells; Immune response; VEGF; Maturation; Suppression. 
1 INTRODUÇÃO 
Células dendríticas (DCs) são as células responsáveis por orquestrar a resposta imunológica por meio da apresentação de antígenos e início da resposta adaptativa através da estimulação de células T. O sistema imunológico tem o potencial de eliminar células neoplásicas naturalmente, fato já evidenciado na remissão espontânea do câncer renal e de melanomas (Bell D et al., 1999). Esta capacidade do sistema imunológico em identificar e destruir células tumorais é conhecida como vigilância imunológica (Burnet, 1971).

A imunidade contra tumores pode ser iniciada por células efetoras da imunidade inata seguida pela ativação da imunidade adaptativa, na qual as células dendríticas (DCs) desempenham papel fundamental.

Vários passos estão envolvidos na vigilância imunológica, incluindo reconhecimento de moléculas tumorais por DCs, captura e apresentação dos antígenos associados a tumores (AAT) pelas DCs, seleção e ativação de células T AAT-específicas e também de células efetoras não específicas como macrófagos e eosinófilos, além da migração das células T AAT-específicas para os sítios tumorais (Paluka et al., 1999). Entretanto, os tumores escapam da imunidade específica devido a alterações nestes passos. Um dos possíveis mecanismos é a supressão da função de DCs por moléculas como a interleucina 10 (IL10) e fator de crescimento endotelial vascular (VEGF), as quais são largamente secretadas por tumores (Zou, 2005).

Uma vez que as DCs maduras são responsáveis pela apresentação de antígenos e estimulação de células T, a diferenciação e/ou maturação anormal das DCs pode levar à imunotolerância.

$\mathrm{Na}$ resposta imunológica às células tumorais, bem como na imunoterapia do câncer, as células dendríticas são um dos principais alvos de estimulação. Muitos métodos de imunoterapia têm sido propostos aproveitando esta capacidade das DCs em processar antígenos, transformá-los em peptídeos e apresentá-los às células efetoras do sistema imunológico (Lesimple et al., 2006; Liu et al., 2006).

Neste estudo, analisaram-se os efeitos causados pelo VEGF no desenvolvimento e maturação de células dendríticas de origem mielóide obtidas de voluntários saudáveis. 


\subsection{Células dendríticas}

As DCs foram identificadas em 1868 na epiderme e denominadas células de Langerhans (Langerhans, 1868), entretanto a presença das DCs em outros tecidos só foi identificada um século depois em 1973 por Steinman e Cohn.

As DCs são consideradas parte do sistema linfohematopoético e para iniciar uma resposta imunológica as DCs devem capturar antígenos de maneira eficiente, processá-los e apresentá-los para as células T antígeno-específicas iniciando sua maturação e expansão (Figura 1).

Antígenos solúveis ou particulados que invadem os tecidos são capturados pelas DCs, após a captura as DCs iniciam sua maturação e migram para órgãos linfóides secundários (Bell et al., 1999). As DCs têm a capacidade de ativar não apenas as células $\mathrm{T}$ de memória, mas as células $\mathrm{T}$ virgens, capacidade que nenhuma outra célula apresentadora de antígeno (APC) possui (Steinman et al., 2003).

Nos órgãos linfóides as DCs ativam as células T antígenos-específicas que se diferenciam não apenas em células $\mathrm{T}$ auxiliares (CD4+) secretoras de linfocinas, mas também em T citotóxicas (CD8+) efetoras, as quais migram para o tecido danificado para eliminar células infectadas por vírus ou para eliminar células tumorais (Figura 1) (Bell et al., 1999). 


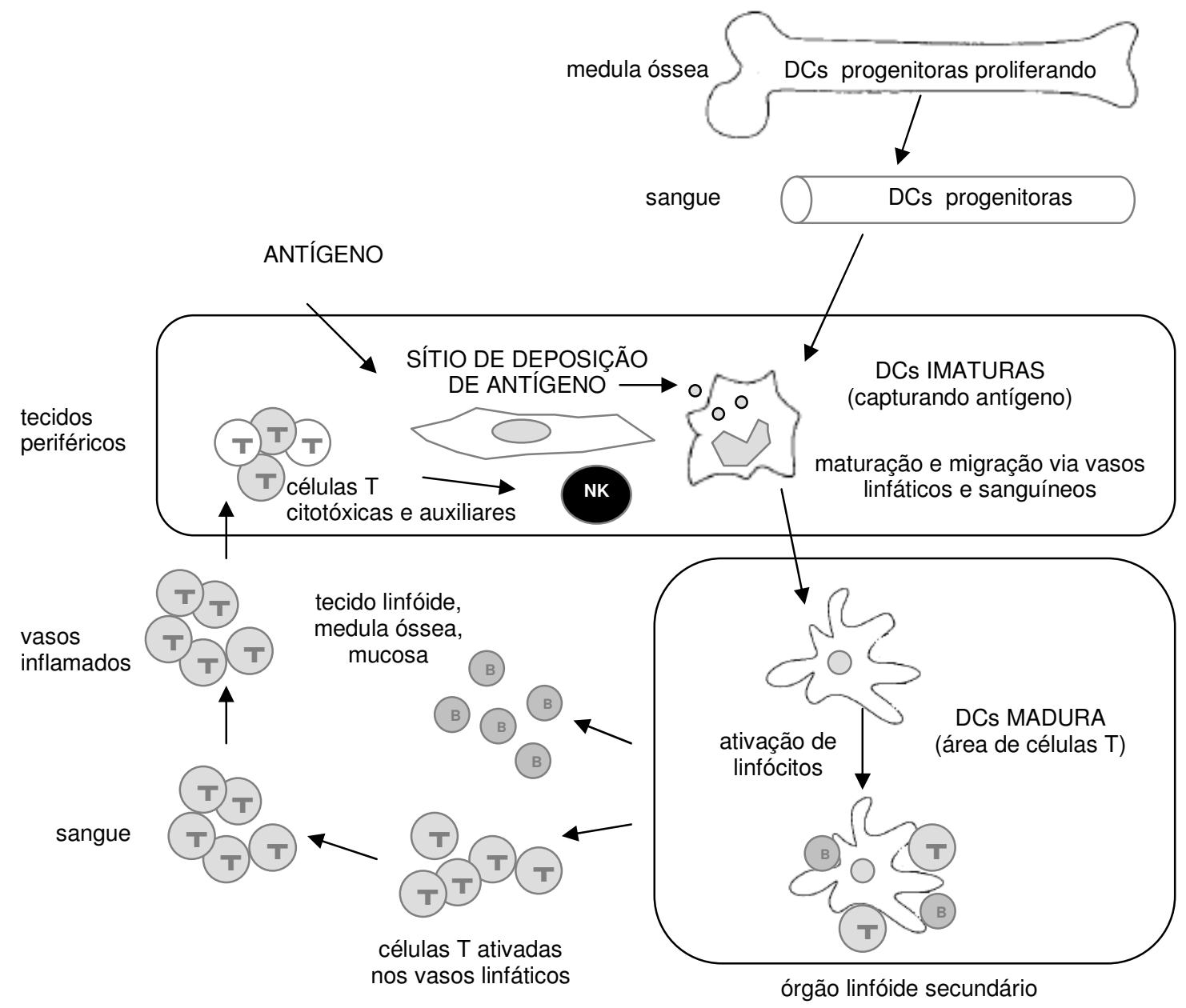

Figura 1 - Captura e apresentação de antígenos por células dendríticas Fonte: Bell et al., (1999).

O conhecimento sobre a fisiologia das DCs evoluiu bastante com a descoberta das técnicas de cultura no início dos anos 90, que possibilitou o cultivo in vitro de um grande número de DCs derivadas de progenitores hematopoéticos.

As DCs compreendem três subtipos (Figura 2), dois são derivados da linhagem mielóide: células de Langerhans (LCs) e DCs intersticiais (DCs); o terceiro subtipo é derivado da linhagem linfóide e conhecido como DCs de origem linfóide (Steinman, 2003). Os precursores de origem mielóide circulam no sangue e foram caracterizados de acordo com a expressão das proteínas de membrana CD14 e CD11c compatível com o fenótipo dos monócitos, ou apenas pela expressão da molécula CD11c (Olweus et al., 1997). Os precursores de origem linfóide são descritos como células que não expressam 
na membrana o marcador de linhagem $\left(\operatorname{Lin}^{\text {neg }}\right)$, CD14 ou CD11c, mas expressam CD123 (receptor de interleucina 3) (Grouard et al., 1997).

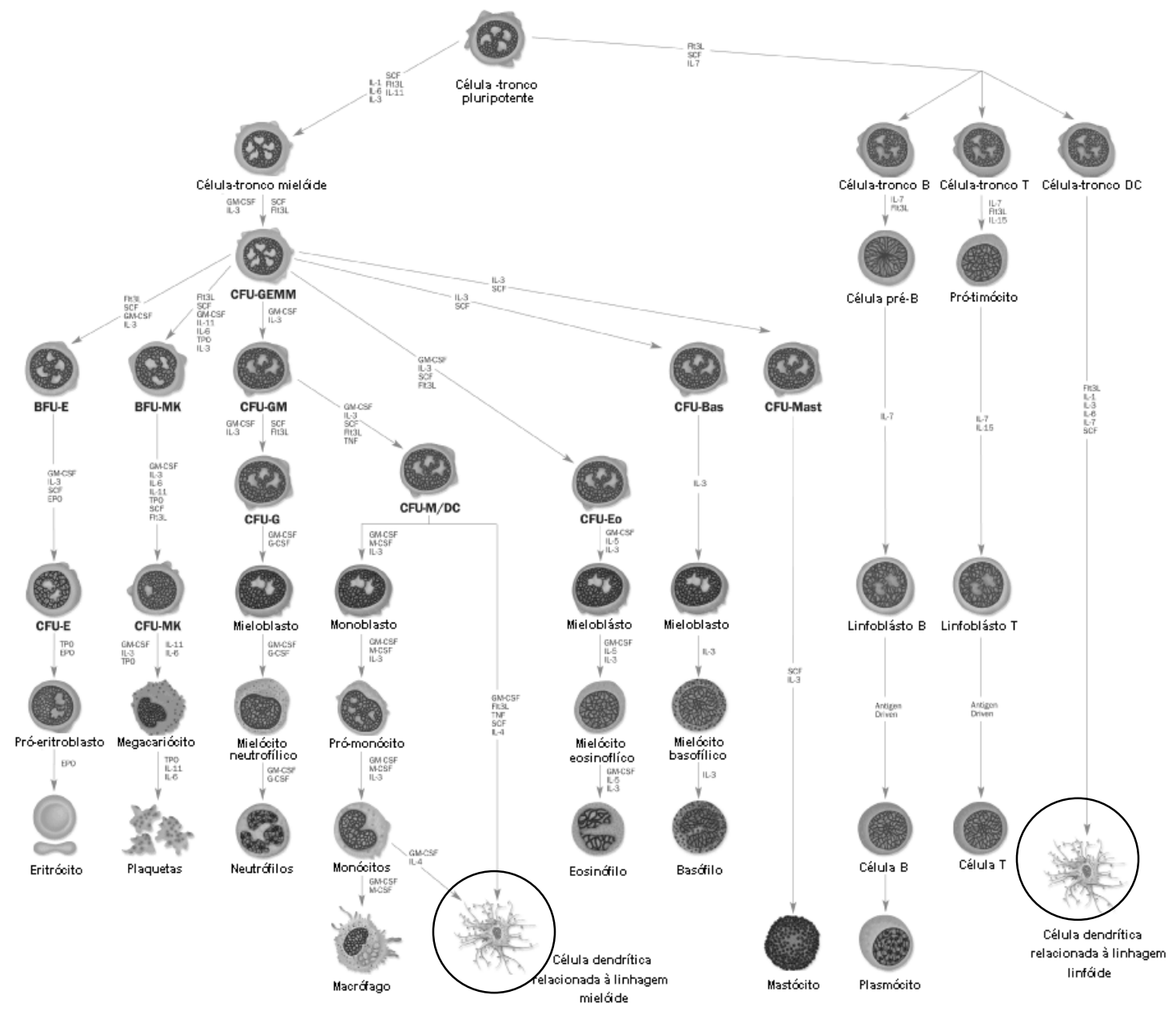

Figura 2 - Esquema que representa a hematopoese. Fonte: Bell D et al. (1999).

Existem três estágios de desenvolvimento: Células precursoras (pré-DC) que circulam pelos vasos sanguíneos e linfáticos; DCs imaturas (iDC) que residem nos diversos tecidos capturando antígenos e as DCs maduras $(\mathrm{mDC})$ residentes temporárias dos órgãos linfóides secundários.

Além de estarem envolvidas no início da resposta imunológica, as DCs também têm importante papel na indução da tolerância imunológica. Em particular as DCs 
presentes no timo apresentam auto-peptídeos para os timócitos recém-gerados, permitindo assim a destruição dos linfócitos auto-reativos (Banchereau et al., 2000).

Existem também evidências do envolvimento das DCs na tolerância periférica, modulando diretamente a função dos linfócitos B e das células natural killer (NK). Estudos em genética molecular também atribuem às DCs novas moléculas que talvez participem na regulação da tolerância periférica como as quimiocinas e receptores de quimiocinas, proteases e anti-proteases, receptores lecitina-like e novos membros da família TNF (Banchereau et al., 2000).

\subsubsection{Morfologia}

In situ, como na pele e em órgãos linfóides as DCs maduras apresentam formato de estrela (Figura 3), pois derivam do centro das DCs muitas projeções em várias direções, estas projeções são finas, medem cerca de $10 \mu \mathrm{m}$ e apresentam raros filamentos de actina (Winzler et al., 1997). Existem evidências de que o formato e a motilidade das DCs estão relacionados com sua função, ou seja, após maturação o formato propicia a seleção e interação das DCs com os raros linfócitos antígeno-específicos (Winzler et al., 1997). 


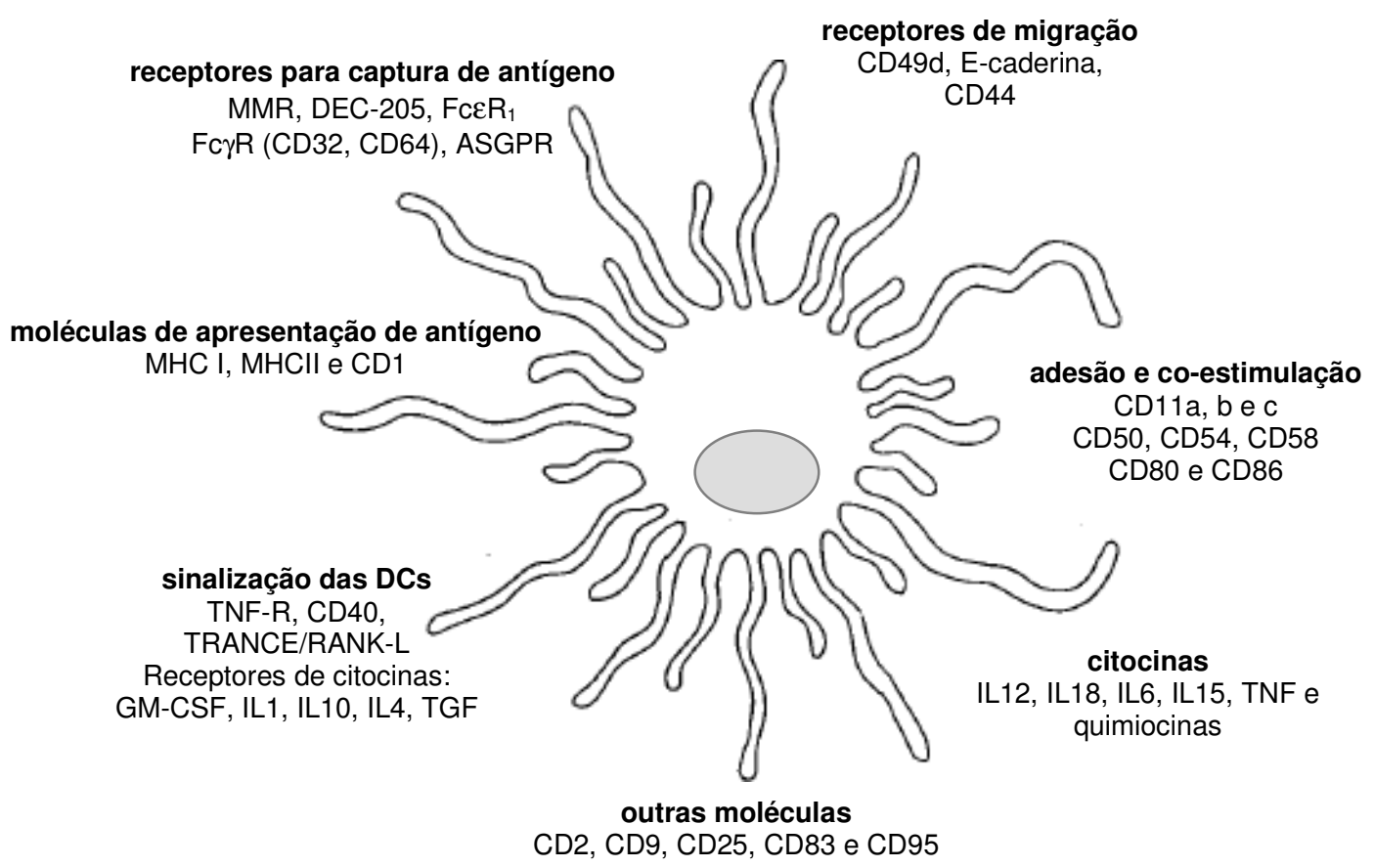

Figura 3 - Morfologia e moléculas expressas pela célula dendrítica. Fonte: Bell D et al. (1999).

\subsubsection{População precursora, DCs imaturas e maduras}

As imDCs estão presentes na maioria dos tecidos e são capazes de capturar antígenos mas não de processar o painel de moléculas acessórias necessárias para uma potente estimulação de células $\mathrm{T}$. Os antígenos capazes de estimular a resposta imunológica são os que iniciam de forma eficiente a maturação das DCs. Os estímulos imunológicos mais potentes para maturação de DCs são os transplantes in vivo (Larsen et al., 1990 e 1994) e contatos com alérgenos (Enk et al., 1993).

As imDCs mais estudadas são certamente as células de Langerhans (LCs), as quais derivam de células-tronco hematopoéticas (Katz et al., 1979). As LCs foram identificadas pela expressão do antígeno CD1a e à presença dos grânulos de Birbeck (estruturas citoplasmáticas formadas por junção de membrana), o que as difere da outra subpopulação de DCs de origem mielóide, pois estas perdem a expressão dos grânulos de Biberck e nem sempre expressam os antígenos CD1 (Davis et al., 1988). 
Após exposição a antígenos ou estímulos inflamatórios, as imDCs migram via vasos linfáticos aferentes, durante a migração se tornam mDCs e se direcionam para as áreas ricas em células $\mathrm{T}$ nos linfonodos, as mDCs também estão presentes nos órgãos linfóides secundários como o baço (Steinman, 1991).

\subsubsection{Processo de maturação}

As DCs evoluem de célula imatura para o estado maduro onde convertem antígenos em imunógenos, secretam moléculas como citocinas, quimiocinas e proteases, expressam moléculas co-estimulatórias na membrana e iniciam a resposta imunológica (Banchereau et al., 1998).

A habilidade das DCs em regular a resposta imunológica é dependente da sua maturação. A maturação é um processo complexo, levando as células a grandes mudanças no fenótipo e função (Figura 4), é acompanhada por reorganização de citoesqueleto (Verdijk et al., 2004), redução da capacidade fagocítica (Apostolopoulos et al., 2001), aquisição de motilidade celular (Benhamron et al., 2006), aumento do potencial de ativação das células T (Forster et al., 1999) e desenvolvimento das expansões citoplasmáticas características denominadas "dendritos" (Averbeck et al., 2004).

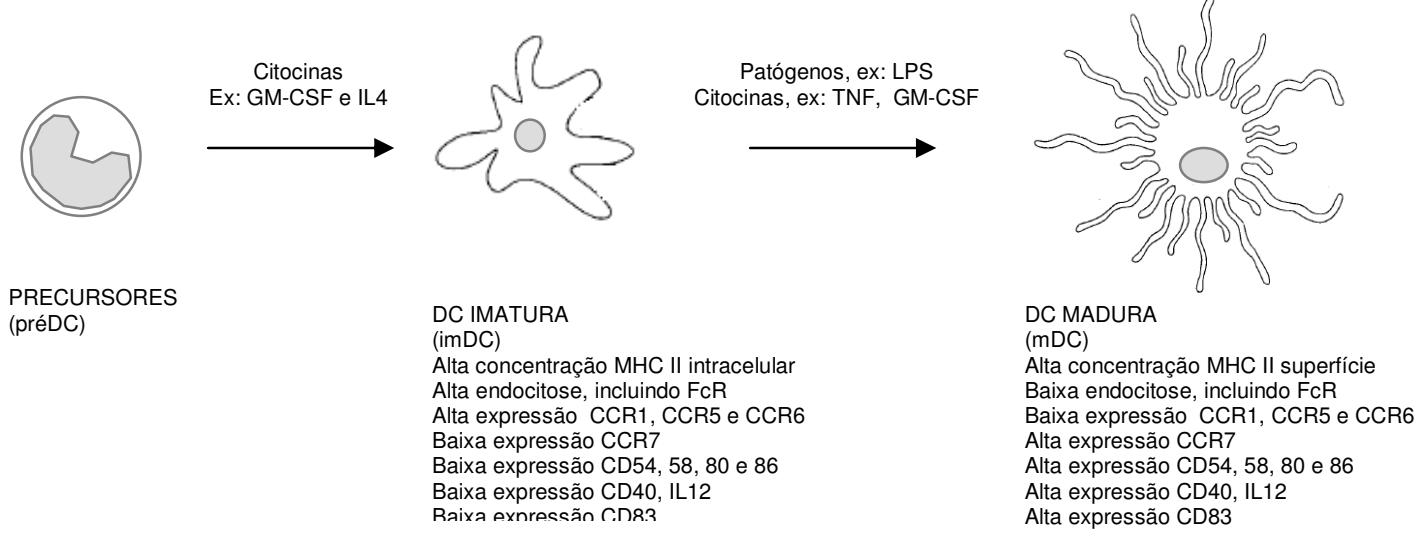

Figura 4 - Estágios de maturação das células dendríticas. Fonte: Reinhard et al. (2002); Bell et al. (1999).

As mDCs expressam moléculas relacionadas à captura e apresentação de antígeno, co-estimulação e migração na superfície da membrana celular; a expressão 
destas moléculas é normalmente utilizada para distinguí-las das imDCs (Figura 4), como o CD83 (Zhou e Tedder, 1995a), uma glicoproteína transmembrana que participa na apresentação de antígenos e também está envolvida na interação célula-célula.

Outras moléculas têm suas expressões aumentadas após a maturação das DCs como, por exemplo, as moléculas co-estimulatórias CD80, CD86, CD40, as moléculas de MHC II envolvidas na apresentação de antígeno e a molécula CCR7 envolvida na migração celular (Cella et al., 1997).

A maturação das DCs é induzida por estímulos, também conhecidos como "sinais de perigo" que ativam as imDCs para a presença de patógenos, inflamação ou dano tecidual.

\subsubsection{Captura de antígeno}

As imDCs internalizam de forma eficiente uma grande variedade de antígenos, os quais são processados e ligados à moléculas de MHC. A captura de antígenos pelas imDCs pode ocorrer por mecanismos distintos: (a) macropinocitose (Sallusto et al., 1995), (b) endocitose mediada por receptores como Fcy e Fce (Sallusto e Lanzavecchia, 1994), (c) endocitose mediada por receptor de manose (Sallusto et al., 1995) ou receptor de lecitina tipo-C (DEC205) (Bonifaz et al., 2002) e (d) fagocitose de corpos apoptóticos através dos receptor de vitronectina $\alpha(\mathrm{v}) \beta 3$ (Rubartelli et al., 1997).

(a) Macropinocitose - é a endocitose de substâncias líquidas dependente do citoesqueleto e mediadas pela formação de grandes vesículas na membrana celular. Nas DCs, a micropinocitose é constitutiva e permite que uma célula englobe grande quantidade de líquidos (Sallusto et al., 1995)

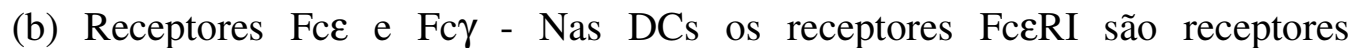
multiméricos compostos de cadeias $\alpha$ e $\gamma$ e inicialmente foram identificadas em basófilos; estas células também expressam o FceRII (CD23) que provavelmente atua na síntese de IgE. Em resposta a estímulos de maturação, as imDCs diminuem a expressão dos receptores Fc para IgGs: Fc $\gamma \mathrm{RI}$ (CD64) e FcRII (CD32), por reduzirem sua capacidade de captura de antígeno por este mecanismo (Sallusto e Lanzavecchia, 1994). 
(c) Receptor de manose e receptor de lecitina tipo-C (DEC-205). As DCs expressam altos níveis de receptores de manose, os quais contêm múltiplos domínios de ligação de carboidrato e estão envolvidos na internalizarão de uma variedade de glicoproteínas. Enquanto os receptores Fc são degradados juntamente com seus ligantes, o receptor de manose libera seu ligante no endossomo e é reciclado. Os receptores de manose têm papel importante na fagocitose de partículas e micróbios. Outro receptor endocítico é o DEC-205 (CD205), uma proteína integral de membrana homóloga ao receptor de manose. O DEC-205 e seu ligante são rapidamente internalizados por vesículas, transportados para compartimento endossomais multivesiculares que se assemelham com as vesículas contendo MHC classe II implicadas na apresentação de antígeno (Bonifaz et al., 2002).

(d) Fagocitose de corpos apoptóticos - As DCs são capazes tanto in vivo como in vitro de capturar e fagocitar células apoptóticas. ImDCs parecem ser mais eficientes do que células dendríticas maduras na captura de corpos apoptóticos e embora macrófagos fagocitem corpos apoptóticos utilizando uma variedade de moléculas de superfície (CD14, CD36, receptores de fosfatidilserina) as DCs usam preferencialmente os receptores de vibronectina $\alpha \mathrm{v} \beta 3$ e o CD36. A fagocitose de corpos apoptóticos induz o aumento de cálcio intracelular $\left[\mathrm{Ca}^{2+}\right]$, o que é essencial para que a fagocitose ocorra. As DCs carregadas de corpos apoptóticos derivados de macrófagos infectados com vírus influenza podem estimular a proliferação de células $\mathrm{T}$ influenza-específicas e gerar células T CD8+ influenza-específicas restritas ao MHC classe I (CTLs). Esta via de sinalização é a via considerada para o fenômeno in vivo do cross-priming, onde antígenos derivados de tumores ou transplantes são apresentados pelas DCs (Rubartelli et al., 1997).

\subsubsection{Apresentação de antígeno}

(a) MHC classe II - Além da eficiente captura de antígeno as DCs necessitam sintetizar e expressar altos níveis de MHC classe II para que a apresentação de antígeno às células $\mathrm{T}$ virgens $(\mathrm{CD} 4+)$ ocorra, causando proliferação de células $\mathrm{T}(\mathrm{CD} 4+)$ específicas (Kleijmeer et al., 1995). Algumas evidências mostram que os endossomos 
tardios e seus derivados lisossomais têm papel crucial na apresentação de antígeno mediada por MHC de Classe II (Pierre e Mellman, 1998).

Durante a maturação das DCs, três estágios seqüenciais são identificados: estágio inicial onde os antígenos do MHC classe II estão localizados nos compartimentos lisossomais; estágio intermediário onde os antígenos do MHC classe II estão localizados em vesículas não lisossomais e estágio final de maturação das DCs onde os complexos peptídeos - MHC classe II estão presentes na membrana celular por longos períodos, permitindo a seleção de raras células T antígeno-específicas (Inaba K et al., 2000; Chow et al., 2002).

(b) MHC classe I - As células apresentadoras de antígeno podem capturar antígenos exógenos e apresentá-los via MHC classe I às células T virgens (CD8+), gerando células T CD8+ citotóxicas efetoras. Experimentos in vitro sugerem 2 vias de sinalização diferentes na apresentação de antígenos exógenos: (a) uma envolvendo a ligação do peptídeo ao MHC classe I pós-Golgi (Harding e Song, 1994) (b) outra envolvendo a via clássica dependente do transportador associado ao processamento de antígeno (TAP) (Rock et al., 1986). Os peptídeos apresentados pelo MHC classe I, podem ser peptídeos derivados de micróbios não replicantes (Norbury et al.,1997), proteínas solúveis (Svenson et al., 1997) ou células apoptóticas (Norbury et al., 1997).

\subsubsection{Moléculas de adesão}

Durante a migração e interação com as células T, as DCs são envolvidas em uma série de eventos de adesão. A expressão do antígeno linfocítico cutâneo (CLA) talvez faça com que a DC possa migrar para a derme interagindo com E-selectina (CD62E) das células endoteliais ativadas (Strunk et al., 1997).

As células de Lagerhans (LCs) se aderem aos queratinócitos através de interações envolvendo E-caderina. Após a captura de antígeno, as LCs diminuem a expressão de Ecadherina, perdendo assim as interações adesivas com os queratinócitos possibilitando sua migração (Tang et al., 1993).

Após estímulos cutâneos com haptenos, observa-se que as LCs produzem colagenase tipo IV (MMP-9) o que provavelmente facilita sua passagem através da membrana basal (Kobayashi, 1997). 
Integrinas e moléculas de adesão intercelular contribuem para a adesão e migração das DCs através da parede de vasos (Jakob et al., 1997). ImDCs podem podem entrar em órgãos linfóides através de vênulas endoteliais de altas vias CD49d $\beta$-integrina (Brown et al., 1997). ICAM-1 (CD54) juntamente com ICAM-2 (CD102) têm sua expressão aumentada nas DCs ativadas e talvez também contribuam para sua migração (Starling et al., 1995).

\subsubsection{Migração}

Apesar das vias de sinalização para migração das DCs serem relativamente bem caracterizadas, os mecanismos moleculares que controlam o recrutamento e migração das DCs são bem menos conhecidos. Fatores quimiotáticos liberados por tecidos e adesinas de superfície estão envolvidos neste processo (Cumberbatch et al., 2001). Várias abordagens mostraram que IL-1 e TNF $\alpha$ estão envolvidas na ativação e mobilização das LCs, estas citocinas agem diminuindo a expressão de E-caderina na superfície das LCs causando a perda de interação com o queratinócitos (Cumberbatch et al., 2001).

As DCs podem tanto responder às quimiocinas como produzí-las: IL-8 (Zhou e Tedder, 1995b), MIP-1 $\alpha$, MIP-1 $\beta$ e RANTES (Sozzani et al., 1995) e MIP-1 $\gamma$ (Mohamadzadeh et al., 1996). Em particular as DCs expressam altos níveis de mRNA para CCR1 (receptor de RANTES), CCR2 (receptor compartilhado de MCP-1 e MCP-3), CCR3 (receptor de eotaxina), CCR5 (Receptor de de MIP-1 $\alpha$, MIP1 $\beta$ e RANTES) e CCR6 (receptor de MIP-3 $\alpha$ ) (Sozzani et al., 1997)

CCR1, CCR5 e CCR6 que são expressos por imDCs e sua expressão diminui durante a maturação (Sozzani et al., 1998). De modo inverso, CCR7, um receptor de MIP-3 $\beta$ não é expresso nas imDCs porém é induzido após a ativação e é presente na DCs maduras (Sozzani et al., 1998).

\subsubsection{Função}

As DCs imaturas têm alta capacidade endocítica e fagocítica, o que permite a captura de antígenos $(\mathrm{Ag})$ e seu processamento. As DCs maduras expressam altos níveis de moléculas co-estimulatórias tendo como principal função a apresentação de Ag. As 
subpopulações de DCs apresentam funções distintas, mas há também evidências de que a função das DCs pode ser alterada por citocinas do meio.

As DCs apresentam considerável variabilidade na capacidade de induzir respostas de células $\mathrm{T}$ auxiliares (CD4+) ou Th e parecem decidir que tipo de resposta Th será ativada. As DCs de origem mielóide secretam IL12 que vai favorecer a diferenciação de células Th0 para Th1, enquanto as DCs de origem linfóide, através de produção de citocinas como IL10 e IL4, favorecem a diferenciação em Th2 (Grouard et al., 1997). Porém este padrão de diferenciação pode ser alterado por citocinas presentes no meio, tais como citocinas anti-inflamatórias secretadas por células T regulatórias (Treg ou Th3). Entre estas citocinas tem-se o fator de crescimento de transformação beta (TGF $\beta$ ) e a interleucina 10 (IL10), também se encontram esteróides e prostaglandinas. (Manome et al., 2000; Zhu et al., 2005).

\subsubsection{Terapia celular}

Tratamentos alternativos utilizando imunoterapia com DCs vêm mostrando resultados promissores no estímulo de respostas efetoras contra certos tumores (Aydin, 2006; Steinman e Banchereau, 2007).

A regressão de tumores ocorre quando linfócitos citotóxicos (CTLs) reconhecem o complexo peptídeo - MHC classe I na superfície do tumor. Para que isto ocorra, as células apresentadoras de antígeno, especificamente DCs, precisam migrar até o tumor, capturar antígenos relacionados ao tumor, migrar aos órgãos linfóides secundários para iniciar as resposta de células T contra antígenos associados ao tumor (TAAg).

Nos tratamentos que utilizam imunoterapia, as DCs dos pacientes são cultivadas in vitro, expostas à TAAg específicos e injetadas nos pacientes.

Têm sido estudadas e desenvolvidas várias formas de se colocar DCs em contato com TAAg in vitro. Muitos autores descrevem a cultura de DCs com peptídeos tumorais específicos (Banchereau et al., 2001). Alguns autores descrevem a exposição das DCs ao RNA total derivado de células tumorais (Boczkowski et al., 2000). Existem também relatos de modificação genética nas DCs utilizando vetores retrovirais que codificam cDNA para um antígeno específico (Specht, 1997; Song et al., 1997). Outros estudos utilizam fusão de DCs e células tumorais para provocar respostas anti-tumorais (Koido et 
al., 2007), entretanto, alguns autores acreditam que apenas o contato entre DCs e células tumorais apoptóticas seja o suficiente para a indução de potente resposta anti-tumoral (D'Hooghe et al., 2007).

Entretanto o sucesso clínico relacionado a estes experimentos são bastante variáveis, embora se tenha comprovado uma forte atividade anti-tumoral das CTLs após imunizações com DCs, ainda existem pontos obscuros que necessitam ser esclarecidos para que o sucesso destas terapias seja definitivo. Principalmente no tangente aos mecanismos que os tumores utilizam para escapar do sistema imunológico e a variabilidade biológica entre indivíduos.

\subsubsection{Células dendríticas e escape de vigilância imunológica por tumores}

Acredita-se que um dos aspectos fundamentais das doenças malignas seja o "escape" da vigilância imunológica, o qual contribui para o crescimento tumoral descontrolado, levando o hospedeiro à morte (Chaux et al., 1997).

Entretanto, a chave na indução de resposta imunológica anti-câncer é a apresentação dos TAAg aos linfócitos T em pacientes portadores de tumores. As células apresentadoras de antígenos têm um papel importante na apresentação de TAAg, função que previamente tinha sido designada predominantemente às próprias células tumorais (Huang et al., 1994).

No entanto, foi demonstrado que DCs isoladas de pacientes com câncer de mama tinham sua capacidade de estimular células $\mathrm{T}$ alogênicas bastante reduzida, o que sugere forte relação entre as DCs e imunidade celular deficiente em câncer de mama (Gabriolovich et al., 1997). Outros autores mostraram que as DCs presentes em sangue periférico de pacientes com câncer de cabeça e pescoço são significantemente imunossuprimidas (Almand et al., 2000).

A presença de DCs imaturas e maduras em adenocarcinoma foi documentada por imunohistoquímica, mostrando heterogeneidade na distribuição destas células. As DCs imaturas foram encontradas infiltrando o tumor e DC maduras foram apenas encontradas nas áreas peri-tumorais (Bell et al., 1999).

Disfunção nas DCs está sendo documentada em vários tumores sólidos em humanos, porém os mecanismos biológicos que levam a está disfunção são pouco 
definidos (Zou et al., 2001; Iwamoto et al., 2003; Troy et al., 1998a; Troy et al., 1998b). Sabe-se que a maturação inadequada destas células pode prejudicar não apenas a apresentação de antígeno como a resposta imunológica sistêmica.

A maturação de DCs pode ser inibida pela presença de moléculas como IL10, MCS-F e VEGF, as quais são amplamente secretadas por células tumorais (Zou, 2005). Embora o VEGF tenha sido associado com ausência de células T ou DCs maduras em câncer de ovário, sua forma de atuação na maturação das DCs é pouco descrita (Zhang et al., 2003).

1.2 Fatores importantes na regulação de células dendríticas.

1.2.1 Fator de crescimento endotelial vascular

\subsubsection{Membros da família VEGF}

Existem vários membros na família de proteínas VEGF, são glicoproteínas mitogênicas de 34 a 43-kDa (Ferrara et al., 1989), específicas para células endoteliais vasculares (Leung et al., 1989) e estão estruturalmente relacionados ao fator de crescimento derivado de plaquetas (PDGF do inglês "platelet derived growth factor") (Dvorak, 2005). Pelo menos 6 membros desta família já foram identificados: VEGFA/fator de permeabilidade vascular (VPF, do inglês "vascular permeability factor") (Dvorak et al., 1991), VEGF-B/ fator relacionado ao VEGF (VRF, do inglês "VEGF related factor") (Olofsson et al., 1996), VEGF-C/ proteína relacionada ao VEGF (VPR, do inglês "VEGF related protein") (Joukov et al., 1997), VEGF-D/ Fator de crescimento induzido c-fos (FIGF do inglês "c-fos induced growth factor"), VEGF-E/em verdade proteína similar ao VEGF, mas codificada por vírus "parapox” (Lyttle et al., 1994) e fator de crescimento placentário (PIGF do inglês "plascenta derived growth factor") (Achen, 1998).

Destes membros, o VEGF-A é o que tem sido mais estudado, por sua importância singular tanto na vasculogênese quanto na angiogênese. Sobre o VEGF-B pouco se sabe, além de seu papel no desenvolvimento da artéria coronária. Os VEGFs C e D são essenciais para o desenvolvimento do sistema linfático. O PlGF foi originalmente 
descoberto na placenta e não é altamente expresso em tecido embrionário ou adulto normal (Cao et al., 2004).

O VEGF-A foi a isoforma escolhida para este estudo, pois é a isoforma envolvida na angiogênese tumoral. O VEGF-A é uma glicoproteína dimérica ligada por pontes dissulfeto de $\sim 45 \mathrm{kD}$, altamente conservada e codificado por um único gene. A ausência de uma das cópias de VEGF-A em embriões de camundongos é letal (Ferrara et al., 2003). A expressão de VEGF-A é regulada em diferentes tecidos e circunstâncias por vários fatores incluindo hipóxia (ex: via HIF-1), citocinas e fatores de crescimento (ex: TGFß) e vários hormônios (ex: estrógeno e progesterona) (Dvorak, 2002).

$\mathrm{O}$ gene do VEGF-A possui 8 éxons que transcrevem 5 ácidos ribonucléicos mensageiros (mRNA) distintos que codificam diferentes tipos de VEGF-A como resultado de um splicing alternativo (Cohen et al., 1995). As isoformas diferem em tamanho: 121, 145, 165, 189 e 206 aminoácidos (Nakamura et al., 2002).

São consideradas as principais isoformas: 121, 165 e 189, estas isoformas apresentam. Apesar destas diferenças físicas, as diferentes isoformas de VEGF-A têm atividades biológicas semelhantes quando em solução, de forma geral, aumentam a permeabilidade vascular, estimulam a sobrevivência, proliferação e migração endotelial (Benjamin e Keshet, 1997).

VEGF $^{165}$ é a isoforma mais estudada e a que mais tem sido associada à angiogênese patológica (Senger et al., 1990). Por este motivo selecionamos esta isoforma para avaliar sua influência na maturação das células dendríticas.

\subsubsection{VEGF e receptores específicos}

As moléculas de VEGF se ligam a receptores celulares específicos através dos quais vão iniciar várias sinalizações. O VEGF-A se liga aos receptores VEGFR1 e VEGFR2, o VEGF-B e PIGF se ligam apenas ao VEGFR1 (Terman et al., 1992), VEGFC e VEGF-D são ligantes específicos do VEGFR3 e regulam a linfoangiogênese (Shen et al., 1993) (Figura 5). O VEGF-E se liga e ativa apenas o VEGFR2 (Ogawa et al., 1998). 


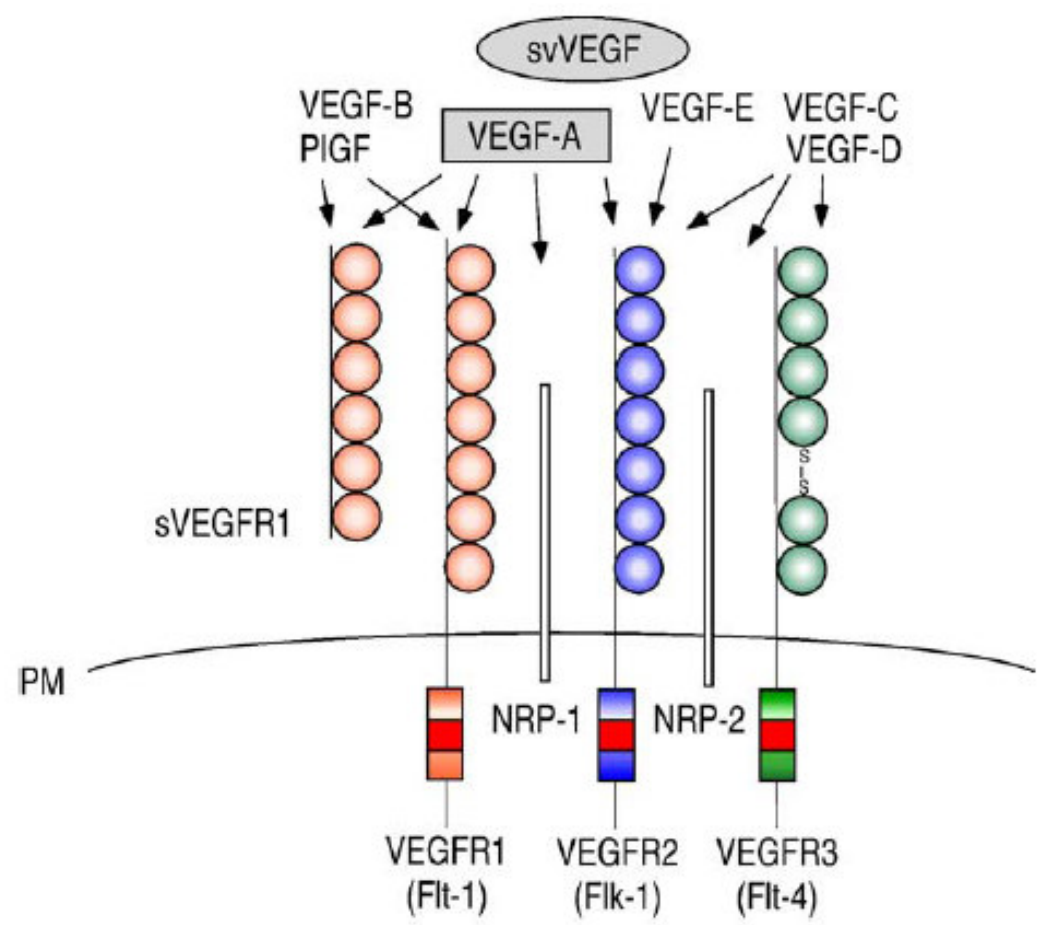

Figura 5 - Esquema que representa o VEGF e seus receptores (Shibuya e Claesson-Welsh, 2006).

A sinalização via VEGFR1 transduz sinais fracos para o crescimento e sobrevivência de células endoteliais e pericitos (células mesenquimais encontradas circundando capilares), bem como para a migração de macrófagos (Sawano et al., 2001).

Várias abordagens identificaram resíduos de tirosina nos domínios intracelulares do VEGFR1 (Y1169, Y1213, Y1242, Y1327, Y1333) como sítios de autofosforilação (Ito et al., 2001). A fosforilação de Y1169 (Figura 6) permite a ligação e ativação de fosfolipase C (PLC $\gamma 1$ do inglês "phospholipase C") regulando a proliferação de células endoteliais via proteína quinase ativada por mitógeno (MAPK do inglês "mitogen activeted protein kinase) (Sawano et al., 2001).

A ativação dos VEGFRs está implicada em uma variedade de patologias incluindo angiogênese tumoral, metástase, doenças inflamatórias como a artrite reumatóide, psoríase, hipertiróidismo e aterosclerose (Alitalo e Carmeliet, 2004).

O VEGFR1 é expresso em monócitos e macrófagos e parece promover a progressão de certas patalogias pelo estímulo da migração de células inflamatórias em doenças como artrite e ateroesclerose (Zhao et al., 2002). Monócitos e macrófagos são 
conhecidos por secretar vários fatores de crescimento pró-angigênicos e linfoangiogênicos, como também proteases. VEGFR1 tem sido relacionado com o aumento de metástase tumoral no pulmão via indução de matriz de metaloproteinase 9 (MMP-9) neste tecido (Hiratsuka et al., 2002).

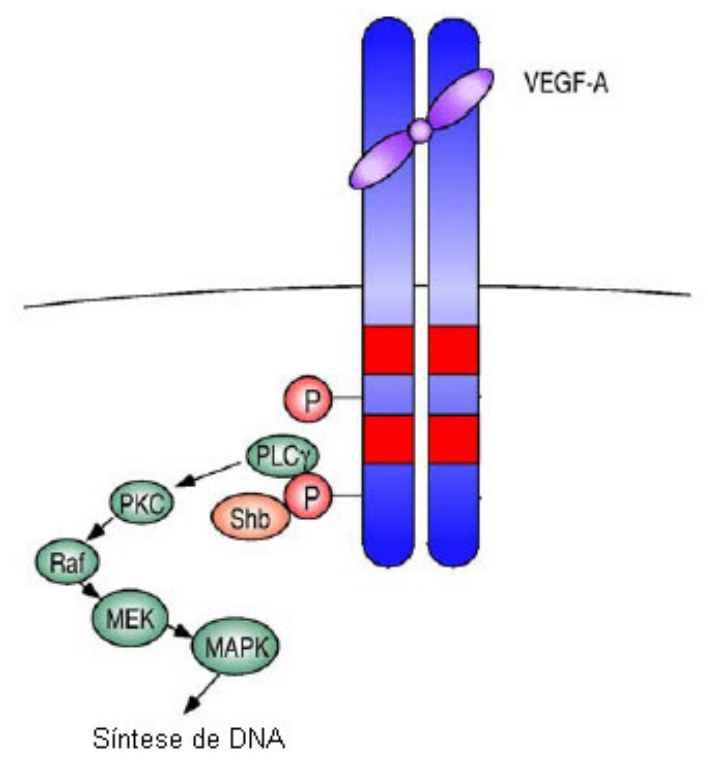

Figura 6 - VEGFR1 e a via de sinalização da PLC $\gamma$ (fosfolipase C) em células endoteliais (Shibuya e Claesson-Welsh, 2006).

O VEGFR2 é um potente regulador das células endoteliais vasculares e está diretamente relacionado à angiogênese tumoral e metástase dependente de veias sanguíneas. O VEGFR1 parece contribuir para vascularização patológica diretamente pelo estímulo das células endoteliais e indiretamente pelo recrutamento de células progenitoras de medula óssea (Carmeliet et al., 2001).

Embora as vias de sinalização específicas em monócitos e macrófagos ou a ação nas vias de diferenciação e maturação de células dendríticas ainda não tenham sido descritas, sabe-se que a exposição das DCs ao VEGF-A inibe sua maturação (Marti et al., 2005). A influência do VEGF-A na maturação das células dendríticas sugere que esta molécula pode estar relacionada com os mecanismos de imunidade e tolerância. 


\subsubsection{3- Atividade biológica do VEGF-A}

De fato, VEGF-A é um dos mais potentes agentes de permebilidade vascular conhecidos, agindo em concentração inferior $1 \mathrm{nmol} / \mathrm{L}$ e com potência muito maior que a histamina (Dvorak et al., 1999).

O aumento da permeabilidade microvascular é a principal atividade biológica do VEGF-A “in vivo" tornando-se evidente 1 minuto após sua injeção. A indução da permeabilidade vascular é essencial e o primeiro passo para angiogênese normal ou fisiológica e angiogênese patológica (Dvorak, 1986). A angiogênese fisiológica tem início no desenvolvimento do feto e continua após o nascimento formando novos vasos sanguíneos normais. Vasos sanguíneos normais são distribuídos em pequenos intervalos regulares e organizados por hierarquia muscular e elástica: artérias, arteríolas, capilares, vênulas pós-capilares, pequenas e grandes veias (Ferrara, 2005). Ao contrário, os vasos sanguíneos novos induzidos por angiogênese em condições patológicas (câncer, doenças cardiovasculares isquêmicas e inflamação crônica), são altamente anormais, ou seja, não estão distribuídos de maneira uniforme, não obedecem a hierarquia arterial-venosa, são funcionalmente heterogêneos e frequentemente são hiperpermeáveis ao plasma e proteínas plasmáticas (Ferrara, 2005).

$\mathrm{O}$ aumento da permeabilidade microvascular pela ação do VEGF-A resulta em extravazamento de proteínas plasmáticas, incluindo fibrinogênio e outras proteínas relacionadas à coagulação. O sistema de coagulação é rapidamente ativado resultando em depósito extravascular de fibrina. A fibrina é um gel, o qual depositado em tecidos tem pelo menos duas grandes conseqüências: 1) a fibrina transforma temporariamente o estroma anti-angiogênico do tecido normal em altamente angiogênico, 2) conjugado com a aparente perda linfática em tumores, a fibrina faz com que o edema persista, resultando no aumento da pressão intersticial, característica da maioria dos tumores sólidos (Boucher e Jain, 1992).

O VEGF-A secretado por tumores causa permeabilidade vascular e extravazamento de plasma na cavidade peritoneal e outras cavidades do corpo levando ao 
acúmulo de líquido ascítico em proporções massivas (vários litros). Este acúmulo de líquidos não é incomum em pacientes com câncer de ovário ou câncer de mama metastático. A imunoreatividade e a bioatividade desta proteína (VEGF-A) é comumente encontrada nestes acúmulos de fluídos relacionados a carcinomas (Olson et al., 1994).

A quantidade de VEGF-A expressa por células tumorais está sendo correlacionada com o prognóstico em muitos tipos de tumores, incluindo câncer de mama, rim, cólon, ovário, cérvix, tireóide, esofago, próstata e tumores de pâncreas (Slaton et al., 2001; Adams et al., 2000; Tabone et al., 2001; Toi et al., 1994). Em todos estes casos, a quantidade de VEGF-A, medida em diferentes estudos por várias técnicas (ex: imunohistoquímica, hibridização "in situ", "western blotting" e PCR) foi correlacionada com um ou mais prognósticos como tamanho do tumor, metástase e sobrevivência em geral (Abdulrauf et al., 1998).

Os níveis de VEGF-A em pacientes com câncer pode ser medido de modo mais conveniente nos fluídos corporais do que em macerados tumorais, o que também é bem documentado. Pacientes com grandes massas tumorais ou metástase apresentam aumento dos níveis de VEGF-A circulante mensurados por ELISA (do inglês " enzyme-linked immunosorbent assay or other assays") ou outros ensaios (Salven et al., 1999).

\subsubsection{Indolamina 2,3-deoxigenase (IDO)}

As células apresentadoras de antígeno como as DCs podem induzir tolerância ou imunidade. Braun et al. (2005) descreveram a presença de IDO durante a maturação de DCs derivadas de monócitos.

A expressão da IDO nas DCs parece estar relacionada a atividade supressora das mesmas tanto nas DCs de origem linfóide como mielóide. As DCs IDO+ podem ser detectadas in vivo e talvez representem um subtipo regulatório das células apresentadoras de antígeno humano.

A ligação entre a molécula CD28 dos linfócitos $\mathrm{T}$ e as moléculas coestimulatórias CD80/CD86 da célula dendrítica induz ativação do linfócito, enquanto que o engajamento da molécula CTLA-4 que se liga com maior avidez às moléculas 
CD80/CD86, tem efeito inibitório. Grohmann et al. (2002) demonstraram que a molécula híbrida de CTLA-4-imunoglobulina ativa DCs via CD80/CD86 e induz a expressão da IDO.

A forte relação da IDO com a imunidade sugere que esta enzima tem um papel tanto na auto-tolerância como na tolerância a novos antígenos. Modulações da expressão de IDO pode também ser um importante mecanismo de "escape" de tumores da vigilância imunológica contra o câncer (Munn e Mellor, 2004).

A enzima IDO foi indentificada pela primeiria vez em 1963, no intestino de coelho, em um trabalho que descreve pela primeira vez os mecanismos de resistência antimicrobiana. A IDO possui efeito antimicrobiano ou anti-tumoral atribuído à depleção de triptofano que é essencial para a proliferação de patógenos intracelulares ou células. Dentro do ambiente metabólico gerado por macrófagos ativados, a probabilidade de um microorganismo ou uma célula tumoral sobreviver é mínima (Nathan e Shiloh, 2000).

$\mathrm{Na}$ última década, ficou evidenciado que a IDO é uma enzima presente em vários tecidos, mas é encontrada particularmente em órgãos linfóides e placenta, sabe-se que a IDO pode ser induzida por IFN- $\gamma$ e que catabolisa triptofano em quinurenina e outros compostos biologicamente ativos (Grohmann et al., 2003).

Em desacordo com os achados anteriores, Munn et al. (1998) mostraram que a tolerância imunológica da gestante em relação ao feto não está relacionada somente à barreira placentária, imaturidade antigênica do feto ou inércia imunológica da gestante como proposto anteriormente por Billingham e Medawar (1953). Esses autores demonstraram que a resposta dos linfócitos maternos contra o feto é inibida pela expressão de IDO nas células da interface materno fetal.

Foi demonstrado experimentalmente que o bloqueio da IDO com 1-metiltriptofano (1-MT) durante a gestação de camundongos é o suficiente para que as células T maternas rejeitem o feto, o que representa uma forte evidência de que a síntese de IDO pelas células placentárias protege os fetos de mamíferos contra o ataque de células $\mathrm{T}$ maternas (Mellor e Munn, 1999). 
7 CONCLUSÃO E PERSPECTIVAS 
Células dendríticas têm sido extensamente estudadas nas últimas duas décadas, principalmente após início de sua utilização em terapia celular na tentativa de induzir resposta imunológica contra tumores. Terapia celular é uma área de grande interesse clínico, porém há muitas variáveis envolvidas neste tipo de terapia e muitas questões ainda sem respostas. Neste estudo analisou-se a influência do VEGF, molécula amplamente secretada por tumores sólidos, na diferenciação e maturação destas células, de forma a ampliar o conhecimento da ação deste fator de crescimento no fenótipo, morfologia e função destas células. As principais conclusões deste estudo estão relacionadas a seguir:

1- Contatou-se a influência do VEGF na maturação das células dendríticas através da variação da expressão da molécula de superfície CD83 determinada por citometria de fluxo. A expressão desta molécula foi significativamente menor nas células expostas ao VEGF. Esta diminuição é um aspecto importante do impacto do VEGF nas DCs, pois o CD83 é não apenas um indicador de maturação, mas também está envolvido na ativação de células T.

2. Alterações morfológicas foram observadas nas células dendríticas maturadas na presença de VEGF, como coloração mais intensa indicando um fenótipo mais basofílico que é característico de células menos especializadas e menor evidência de prolongamentos citoplasmáticos, também chamados dendritos, quando comparada com as células não tratadas. Estas alterações morfológicas mostraram o impacto do VEGF no rearranjo do citoesqueleto das células dendríticas durante sua maturação, o que também pode influenciar sua função de apresentação de antígeno, principalmente na interação célula-célula.

3. Alterações na expressão gênica foram observadas em células dendríticas maturadas na presença de VEGF, embora grande parte dos genes diferencialmente expressos sejam distintos entre as amostras biológicas, refletindo a variabilidade biológica entre indivíduos, quando esses genes eram agrupados em classes funcionais encontramos 
resultados semelhantes. As vias relacionadas com adesão celular e/ou citoesqueleto estavam super-expressas nas células dendríticas tratadas com VEGF quando comparadas com as não tratadas. Corroborando os achados morfológicos a expressão gênica mostra que o VEGF pode ter impacto no rearranjo do citoesqueleto das células dendríticas durante sua maturação e ainda indica que a super-expressão de integrinas pode interferir na capacidade de migração destas células.

4. Detectamos que a enzima IDO (indolamina-2,3-deoxigenase) estava mais expressa nas células tratadas com VEGF quando comparadas com as não tratadas. Isso corrobora a idéia de que o VEGF não interfere apenas na expressão de moléculas relacionadas com a maturação das células dendríticas, mas também com a intensidade de expressão de moléculas envolvidas na tolerância imunológica.

5. Utilizando o modelo da reação mista de leucócitos em presença do antígeno de Candida albicans, observamos redução de $30 \%$ da capacidade apresentação de antígenos das células dendríticas tratadas com VEGF. As alterações morfológicas observadas por microscopia, a super-expressão de genes relacionados ao citoesqueleto detectadas em células tratadas com VEGF, bem como a menor expressão da molécula CD83 e o aumento de expressão da enzima IDO certamente contribuem para essa redução da capacidade de apresentação de antígenos e de proliferação de linfócitos. 
REFERÊNCIAS BIBLIOGRÁFICAS 
Abdulrauf SI, Edvardsen K, Ho KL, Yang XY, Rock JP, Rosenblum ML.Vascular endothelial growth factor expression and vascular density as prognostic markers of survival in patients with low-grade astrocytoma. J Neurosurg. 1998 Mar;88(3):513-20.

Achen MG, Jeltsch M, Kukk E, Makinen T, Vitali A, Wilks AF, Alitalo K, Stacker SA. Vascular endothelial growth factor D (VEGF-D) is a ligand for the tyrosine kinases VEGF receptor 2 (Flk1) and VEGF receptor 3 (Flt4).Proc Natl Acad Sci U S A. 1998 Jan 20;95(2):548-53.

Adams J, Carder PJ, Downey S, Forbes MA, MacLennan K, Allgar V, Kaufman S, Hallam S, Bicknell R, Walker JJ, Cairnduff F, Selby PJ, Perren TJ, Lansdown M, Banks RE. Vascular endothelial growth factor (VEGF) in breast cancer: comparison of plasma, serum, and tissue VEGF and microvessel density and effects of tamoxifen. Cancer Res. 2000 Jun 1;60(11):2898-905.

Al-Alwan MM, Rowden G, Lee TD, West KA. The dendritic cell cytoskeleton is critical for the formation of the immunological synapse. J Immunol. 2001 Feb 1;166(3):1452-6.

Alitalo K, Carmeliet P. Molecular mechanisms of lymphangiogenesis in health and disease.Cancer Cell. 2002 Apr;1(3):219-27.

Almand B, Resser JR, Lindman B, Nadaf S, Clark JI, Kwon ED, Carbone DP, Gabrilovich DI Clinical significance of defective dendritic cell differentiation in cancer. Clin Cancer Res. 2000 May;6(5):1755-66.

Apostolopoulos V, McKenzie IF. Role of the mannose receptor in the immune response. Curr Mol Med, 2001; 1(4):469-74.

Averbeck M, Braun T, Pfeifer G, Sleeman J, Dudda J, Martin SF, Kremer B, Aktories K, Simon JC, Termeer C. Early cytoskeletal rearrangement during dendritic cell maturation enhances synapse formation and $\mathrm{Ca}(2+)$ signaling in $\mathrm{CD} 8(+) \mathrm{T}$ cells. Eur J Immunol, 2004; 34(10):2708-19.

Aydin N, Jack A, Montenegro G, Boyes C, Alam K, Wallack MK. Expression of Melanoma-Associated Antigens in Human Dendritic Cells Pulsed with an Interleukin-2 Gene Encoded Vaccinia Melanoma Oncolysate (rIL-2VMO). Cancer Biol Ther. 2006 Dec;5(12):1654-7. Epub 2006 Dec 7.

Banchereau J, Steinman RM. Dendritic cells and the control of immunity. Nature. 1998 Mar 19;392(6673):245-52.

International Committee of Medical Journal Editors. Uniform requirements for manuscripts submitted to Biomedical Journal: samples references. Available from: http://www.icmje.org [2004 May 06]. 
Banchereau J, Briere F, Caux C, Davoust J, Lebecque S, Liu YJ, Pulendran B, Palucka K. Immunobiology of dendritic cells. Annu Rev Immunol. 2000;18:767-811.

Banchereau J, Palucka AK, Dhodapkar M, Burkeholder S, Taquet N, Rolland A, Taquet S, Coquery S, Wittkowski KM, Bhardwaj N, Pineiro L, Steinman R, Fay J. Immune and clinical responses in patients with metastatic melanoma to $\mathrm{CD} 34(+)$ progenitor-derived dendritic cell vaccine. Cancer Res. 2001 Sep 1;61(17):6451-8.

Benjamin LE, Keshet E. Conditional switching of vascular endothelial growth factor (VEGF) expression in tumors: induction of endothelial cell shedding and regression of hemangioblastoma-like vessels by VEGF withdrawal. Proc Natl Acad Sci U S A. 1997 Aug 5;94(16):8761-6.

Bell D, Young JW, Banchereau J. Dendritic cell. Adv Immunol. 1999; 72:255-324.

Benhamron S, Nechushtan H, Verbovetski I, Krispin A, Abboud-Jarrous G, Zcharia E, Edovitsky E, Nahari E, Peretz T, Vlodavsky I, Mevorach D. Translocation of active heparanase to cell surface regulates degradation of extracellular matrix heparan sulfate upon transmigration of mature monocyte-derived dendritic cells. J Immunol, 2006 Jun 1;176(11):6417-24.

Billingham RE, Brent L, Medawar PB. Quantitative studies on tissue transplantation immunity. II. The origin, strength and duration of actively and adoptively acquired immunity. Proc R Soc Lond B Biol Sci. 1954 Dec 15;143(910):58-80.

Boczkowski D, Nair SK, Nam JH, Lyerly HK, Gilboa E. Induction of tumor immunity and cytotoxic $\mathrm{T}$ lymphocyte responses using dendritic cells transfected with messenger RNA amplified from tumor cells. Cancer Res. 2000 Feb 15;60(4):1028-34.

Bonifaz L, Bonnyay D, Mahnke K, Rivera M, Nussenzweig MC, Steinman RM. Efficient targeting of protein antigen to the dendritic cell receptor DEC-205 in the steady state leads to antigen presentation on major histocompatibility complex class I products and peripheral CD8+ T cell tolerance. J Exp Med. 2002 Dec 16;196(12):1627-38

Boucher Y, Jain RK. Microvascular pressure is the principal driving force for interstitial hypertension in solid tumors: implications for vascular collapse. Cancer Res. 1992 Sep 15;52(18):5110-4.

Braun D, Longman RS, Albert ML. A two-step induction of indoleamine 2,3 dioxygenase (IDO) activity during dendritic-cell maturation. Blood. 2005 Oct 1;106(7):2375-81. Epub 2005 Jun 9.

Brown KA, Bedford P, Macey M, McCarthy DA, Leroy F, Vora AJ, Stagg AJ, Dumonde DC, Knight SC. Human blood dendritic cells: binding to vascular endothelium and expression of adhesion molecules. Clin Exp Immunol. 1997 Mar;107(3):601-7. 
Burnet FM. Immunological surveillance in neoplasia. Transplant Rev. 1971; 7:3-25.

Carmeliet P, Moons L, Luttun A, Vincenti V, Compernolle V, De Mol M, Wu Y, Bono F, Devy L, Beck H, Scholz D, Acker T, DiPalma T, Dewerchin M, Noel A, Stalmans I, Barra A, Blacher S, Vandendriessche T, Ponten A, Eriksson U, Plate KH, Foidart JM, Schaper W, Charnock-Jones DS, Hicklin DJ, Herbert JM, Collen D, Persico MG. Synergism between vascular endothelial growth factor and placental growth factor contributes to angiogenesis and plasma extravasation in pathological conditions. Nat Med. 2001 May;7(5):575-83.

Cao R, Eriksson A, Kubo H, Alitalo K, Cao Y, Thyberg J. Comparative evaluation of FGF-2-, VEGF-A-, and VEGF-C-induced angiogenesis, lymphangiogenesis, vascular fenestrations, and permeability. Circ Res. 2004 Mar 19;94(5):664-70

Cella M, Engering A, Pinet V, Pieters J, Lanzavecchia A. Inflammatory stimuli induce accumulation of MHC class II complexes on dendritic cells. Nature, 1997; 388 (6644):782-7.

Chaux P, Favre N, Martin M, Martin F. Tumor-infiltrating dendritic cells are defective in their antigen-presenting function and inducible B7 expression in rats. Int J Cancer. 1997 Aug 7;72(4):619-24.

Chen HL, Gabrilovich D, Tampé R, Girgis KR, Nadaf S, Carbone DP. A functionally defective allele of TAP1 results in loss of MHC class I antigen presentation in a human lung cancer. Nat Genet. 1996 Jun;13(2):210-3.

Chow A, Toomre D, Garrett W, Mellman I. Dendritic cell maturation triggers retrograde MHC class II transport from lysosomes to the plasma membrane. Nature. 2002 Aug 29;418(6901):988-94.

Cohen T, Gitay-Goren H, Sharon R, Shibuya M, Halaban R, Levi BZ, Neufeld G. VEGF121, a vascular endothelial growth factor (VEGF) isoform lacking heparin binding ability, requires cell-surface heparan sulfates for efficient binding to the VEGF receptors of human melanoma cells. J Biol Chem. 1995 May 12; 270(19):11322-6.

Cumberbatch M, Dearman RJ, Antonopoulos C, Groves RW, Kimber I. Interleukin (IL)18 induces Langerhans cell migration by a tumour necrosis factor-alpha- and IL-1betadependent mechanism. Immunology. 2001 Mar;102(3):323-30.

Davis AL, McKenzie JL, Hart DN. HLA-DR-positive leucocytes subpopulations in human skin include dendritic cells, macrophages, and CD7-negative $\mathrm{T}$ cells. Immunology. 1988 Dec;65(4):573-81.

D' Hooghe E, Buttiglieri S, Bisignano G, Brusa D, Camussi G, Matera L. Apoptic renal carcinoma cells are better inducers of cross-presenting activity than their primary necrotic counterpart. Int J Immunopathol Pharmacol. 2007 Oct-Dec;20(4):707-17. 
Dvorak HF. Angiogenesis: update 2005. J Thromb Haemost. 2005 Aug;3(8):1835-42.

Dvorak HF. Vascular permeability factor/vascular endothelial growth factor: a critical cytokine in tumor angiogenesis and a potential target for diagnosis and therapy. J Clin Oncol. 2002 Nov 1;20(21):4368-80.

Dvorak HF. Tumors: wounds that do not heal. Similarities between tumor stroma generation and wound healing. N Engl J Med. 1986 Dec 25;315(26):1650-9.

Dvorak HF, Nagy JA, Feng D, Brown LF, Dvorak AM. Vascular permeability factor/vascular endothelial growth factor and the significance of microvascular hyperpermeability in angiogenesis. Curr Top Microbiol Immunol. 1999;237:97-132.

Dvorak HF, Sioussat TM, Brown LF, Berse B, Nagy JA, Sotrel A, Manseau EJ, Van de Water L, and Senger DR. Distribution of vascular permeability factor (vascular endothelial growth factor) in tumors: concentration in tumor blood vessels. J Exp Med. 1991 174: 1275-1278.

Enk AH, Angeloni VL, Udey MC, Katz SI. An essential role for Langerhans cell-derived IL-1 beta in the initiation of primary immune responses in skin. J Immunol. 1993 May 1;150(9):3698-704.

Feijoó E, Alfaro C, Mazzolini G, Serra P, Peñuelas I, Arina A, Huarte E, Tirapu I, Palencia B, Murillo O, Ruiz J, Sangro B, Richter JA, Prieto J, Melero I. Dendritic cells delivered inside human carcinomas are sequestered by interleukin-8. Int J Cancer. 2005 Aug 20;116(2):275-81.

Ferrara N. The role of VEGF in the regulation of physiological and pathological angiogenesis. EXS. 2005;(94):209-31.

Ferrara N, Gerber HP, LeCouter J. The biology of VEGF and its receptors. Nat Med. 2003 Jun; 9(6):669-76.

Ferrara, N., Henzel, W. J. Pituitary follicular cells secrete a novel heparin-binding growth factor specific for vascular endothelial cells. Biochem Biophys Res Commun. 161: 851-858, 1989.

Forster R, Schubel A, Breitfeld D, Kremmer E, Renner-Muller I, Wolf E, Lipp M. CCR7 coordinates the primary immune response by establishing functional microenvironments in secondary lymphoid organs. Cell, 1999; 99(1):23-33.

Gabrilovich DI, Corak J, Ciernik IF, Kavanaugh D, Carbone DP. Decreased antigen presentation by dendritic cells in patients with breast cancer. Clin Cancer Res. 1997 Mar;3(3):483-90. 
Grohmann U, Orabona C, Fallarino F, Vacca C, Calcinaro F, Calendoro P, Belladonna ML, Bianchi R, Fioretti MC, Pucetti P. CTLA-4-Ig regulates tryptophan catabolism in vivo. Nat Immunol. 2002; 3(11):1097-101.

Grohmann U, Fallarino F, Peccetti P. Tolerance, DCs and tryptophan: much ado about IDO. Trends Immunol. 2003; 24(5):242-248.

Grouard G, Rissoan MC, Filgueira L, Durand I, Banchereau J, Liu YJ. The enigmatic plasmacytoid T cells develop into dendritic cells with interleukin (IL)-3 and CD40ligand. J Exp Med. 1997 Mar 17; 185(6):1101-11.

Harding CV, Song R. Phagocytic processing of exogenous particulate antigens by macrophages for presentation by class I MHC molecules. J Immunol. 1994 Dec 1;153(11):4925-33.

Hiratsuka S, Nakamura K, Iwai S, Murakami M, Itoh T, Kijima H, Shipley JM, Senior RM, Shibuya M. MMP9 induction by vascular endothelial growth factor receptor-1 is involved in lung-specific metastasis. Cancer Cell. 2002 Oct; 2(4):289-300.

Houck KA, Leung DW, Rowland AM, Winer J, Ferrara N. Dual regulation of vascular endothelial growth factor bioavailability by genetic and proteolytic mechanisms. J Biol Chem. 1992 Dec 25;267(36):26031-7.

Huang AY, Golumbek P, Ahmadzadeh M, Jaffee E, Pardoll D, Levitsky H. Role of bone marrow-derived cells in presenting MHC class I-restricted tumor antigens. Science. 1994 May 13;264(5161):961-5.

Inaba K, Turley S, Iyoda T, Yamaide F, Shimoyama S, Reis e Sousa C, Germain RN, Mellman I, Steinman RM. The formation of immunogenic major histocompatibility complex class II-peptide ligands in lysosomal compartments of dendritic cells is regulated by inflammatory stimuli. J Exp Med. 2000 Mar 20;191(6):927-36.

Ito N, Huang K, Claesson-Welsh L. Signal transduction by VEGF receptor-1 wild type and mutant proteins. Cell Signal. 2001 Nov; 13(11):849-54.

Iwamoto M, Shinohara H, Miyamoto A, Okuzawa M, Mabuchi H, Nohara T, Gon G, Toyoda M, Tanigawa N. Prognostic value of tumor-infiltrating dendritic cells expressing CD83 in human breast carcinomas. Int J Cancer. 2003 Mar 10;104(1):92-7.

Jakob T, Saitoh A, Udey MC. E-cadherin-mediated adhesion involving Langerhans celllike dendritic cells expanded from murine fetal skin. J Immunol. 1997 Sep 15;159(6):2693-701.

Joukov V, Kaipainen A, Jeltsch M, Pajusola K, Olofsson B, Kumar V, Eriksson U, Alitalo K. Vascular endothelial growth factors VEGF-B and VEGF-C. J Cell Physiol. 1997 Nov; 173(2):211-5. 
Junqueira LC, Carneiro J. Histologia básica. Rio de Janeiro: Editora Guanabara Koogan S.A.; 2004. p. 242-250.

Katz SI, Tamaki K, Sachs DH. Epidermal Langerhans cells are derived from cells originating in bone marrow. Nature. 1979 Nov 15;282(5736):324-6.

Koide T, Salem-Izacc SM, Gomes SL, Vêncio RZ. SpotWhatR: a user-friendly microarray data analysis system. Genet Mol Res. 2006 Mar 31;5(1):93-107.

Kiertscher SM, Luo J, Dubinett SM, Roth MD. Tumors promote altered maturation and early apoptosis of monocyte-derived dendritic cells. J Immunol. 2000 Feb 1;164(3):126976.

Kim R, Emi M, Tanabe K. Functional roles of immature dendritic cells in impaired immunity of solid tumour and their targeted strategies for provoking tumour immunity. Clin Exp Immunol. 2006 Nov;146(2):189-96.

Kleijmeer MJ, Ossevoort MA, van Veen CJ, van Hellemond JJ, Neefjes JJ, Kast WM, Melief CJ, Geuze HJ. MHC class II compartments and the kinetics of antigen presentation in activated mouse spleen dendritic cells. J Immunol. 1995 Jun 1;154(11):5715-24.

Kobayashi Y. Langerhans' cells produce type IV collagenase (MMP-9) following epicutaneous stimulation with haptens. Immunology. 1997 Apr;90(4):496-501.

Koido S, Hara E, Homma S, Fujise K, Gong J, Tajiri H. Dendritic/tumor fusion cellbased vaccination against cancer. Arch Immunol Ther Exp (Warsz). 2007 SepOct;55(5):281-7.

Langerhans P. Virchows Arch Anat., 1868, 44, 325.

Larsen CP, Steinman RM, Witmer-Pack M, Hankins DF, Morris PJ, Austyn JM. Migration and maturation of Langerhans cells in skin transplants and explants. J Exp Med. 1990 Nov 1;172(5):1483-93.

Larsen CP, Ritchie SC, Hendrix R, Linsley PS, Hathcock KS, Hodes RJ, Lowry RP, Pearson TC. Regulation of immunostimulatory function and costimulatory molecule (B71 and B7-2) expression on murine dendritic cells. J Immunol. 1994 Jun 1;152(11):520819.

Laxmanan S, Robertson SW, Wang E, Lau JS, Briscoe DM, Mukhopadhyay D. Vascular endothelial growth factor impairs the functional ability of dendritic cells through Id pathways. Biochem Biophys Res Commun. 2005 Aug 19;334(1):193-8 
Lesimple T, Neidhard EM, Vignard V, Lefeuvre C, Adamski H, Labarriere N, Carsin A, Monnier D, Collet B, Clapisson G, Birebent B, Philip I, Toujas L, Chokri M, Quillien V. Immunologic and clinical effects of injecting mature peptide-loaded dendritic cells by intralymphatic and intranodal routes in metastatic melanoma patients. Clin Cancer Res. 2006 Dec 15;12(24):7380-8.

Leung DW, Cachianes G, Kuang WJ, Goeddel DV, Ferrara N. Vascular endothelial growth factor is a secreted angiogenic mitogen. Science. 1989; 246:1306-9.

Liu G, Black KL, Yu JS. Sensitization of malignant glioma to chemotherapy through dendritic cell vaccination. Expert Rev Vaccines. 2006 Apr;5(2):233-47.

Lyttle DJ, Fraser KM, Fleming SB, Mercer AA, Robinson AJ. Homologs of vascular endothelial growth factor are encoded by the poxvirus orf virus. J Virol. 1994 Jan; 68 (1):84-92.

Manome H, Aiba S, Singh S, Yoshino Y, Tagami H. Dexamethasone and cyclosporin A affect the maturation of monocyte-derived dendritic cells differently. Int Arch Allergy Immunol. 2000 May;122(1):76-84.

Marti L.C., Tobo P.R.; Carvalho A.C.S.R.; Carmo A.O.; Okamoto O.K.; Moreira-Filho, C.A. Vascular endothelial growth factor inhibits dendritic cell maturation process. Einstein, 3(1):14-18, 2005.

Mellor AL, Munn DH. Tryptophan catabolism and T-cell tolerance: immunosuppression by starvation? Immunol Today. 1999; 20(10):469-73.

Mellor AL, Baban B, Chandler P, Marshall B, Jhaver K, Hansen A, Koni PA, Iwashima M, Munn DH.Cutting edge: induced indoleamine 2,3 dioxygenase expression in dendritic cell subsets suppresses T cell clonal expansion. J Immunol. 2003 Aug 15;171(4):1652-5.

Mohamadzadeh M, Poltorak AN, Bergstressor PR, Beutler B, Takashima A. Dendritic cells produce macrophage inflammatory protein-1 gamma, a new member of the CC chemokine family. J Immunol. 1996 May 1;156(9):3102-6.

Mosca PJ, Hobeika AC, Clay TM, Nair SK, Thomas EK, Morse MA, Lyerly HK. A subset of human monocyte-derived dendritic cells expresses high levels of interleukin-12 in response to combined CD40 ligand and interferon-gamma treatment. Blood. 2000 Nov 15;96(10):3499-504.

Muller AJ, Prendergast GC. Indoleamine 2,3-dioxygenase in immune suppression and cancer. Curr Cancer Drug Targets. 2007 Feb;7(1):31-40.

Munn DH, Zhou M, Attwood JT, Bondarev I, Conway SJ, Marshall B, Brown C, Mellor AL. Prevention of allogeneic fetal rejection by tryptophan catabolism. Science. 1998; 281(5380):1191-3. 
Munn DH, Mellor AL. IDO and tolerance to tumors. TRENDS in Molecular Medicine. 2004;10(1):15-18.

Nakamura M, Abe Y, Tokunaga T. Pathological significance of vascular endothelial growth factor A isoform expression in human cancer. Pathol Int. 2002 May-Jun;52(56):331-9.

Nathan C, Shiloh MU. Reactive oxygen and nitrogen intermediates in the relationship between mammalian hosts and microbial pathogens. Proc Natl Acad Sci U S A. 2000; 97(16): 8841-8.

Norbury CC, Chambers BJ, Prescott AR, Ljunggren HG, Watts C. Constitutive macropinocytosis allows TAP-dependent major histocompatibility complex class I presentation of exogenous soluble antigen by bone marrow-derived dendritic cells. Eur $\mathbf{J}$ Immunol. 1997 Jan;27(1):280-8

Ogawa S, Oku A, Sawano A, Yamaguchi S, Yazaki Y, Shibuya M. A novel type of vascular endothelial growth factor, VEGF-E (NZ-7 VEGF), preferentially utilizes KDR/Flk-1 receptor and carries a potent mitotic activity without heparin-binding domain. J Biol Chem. 1998 Nov 20; 273(47):31273-82.

Olofsson B, Pajusola K, Kaipainen A, von Euler G, Joukov V, Saksela O, Orpana A, Pettersson RF, Alitalo K, Eriksson U. Vascular endothelial growth factor B, a novel growth factor for endothelial cells. Proc Natl Acad Sci USA. 1996 Mar 19; 93(6):257681.

Olson TA, Mohanraj D, Carson LF, Ramakrishnan S. Vascular permeability factor gene expression in normal and neoplastic human ovaries. Cancer Res. 1994 Jan 1;54(1):27680.

Oyama T, Ran S, Ishida T, Nadaf S, Kerr L, Carbone DP, Gabrilovich DI. Vascular endothelial growth factor affects dendritic cell maturation through the inhibition of nuclear factor-kappa B activation in hemopoietic progenitor cells. J Immunol. 1998 Feb $1 ; 160(3): 1224-32$.

Olweus J, BitMansour A, Warnke R, Thompson PA, Carballido J, Picker LJ, LundJohansen F. Dendritic cell ontogeny: a human dendritic cell lineage of myeloid origin. Proc Natl Acad Sci USA. 1997 Nov 11;94(23):12551-6.

Palecek SP, Loftus JC, Ginsberg MH, Lauffenburger DA, Horwitz AF.Integrin-ligand binding properties govern cell migration speed through cell-substratum adhesiveness. Nature. 1997 Feb 6;385(6616):537-40.

Palucka K, Fay J, Banchereau J, Dendritic cell and tumor immunity. Curr Opin. Oncol. Endocrine Metabolic Invest Drug. 1999; 1:282-90. 
Pierre P, Mellman I. Developmental regulation of invariant chain proteolysis controls MHC class II trafficking in mouse dendritic cells. Cell. 1998 Jun 26;93(7):1135-45.

Prechtel AT, Turza NM, Theodoridis AA, Steinkasserer A. CD83 knockdown in monocyte-derived dendritic cells by small interfering RNA leads to a diminished $\mathrm{T}$ cell stimulation. J Immunol. 2007 May 1;178(9):5454-64.

Reinhard G, Marten A, Kiske SM, Feil F, Bieber T, Schmidt-Wolf Generation of dendritic cell-based vaccines for cancer therapy. Br J Cancer. 2002 May 20;86(10):152933.

Rock KL, Yeh ET, Gramm CF, Haber SI, Reiser H, Benacerraf B. TAP, a novel T cellactivating protein involved in the stimulation of MHC-restricted T lymphocytes. J Exp Med. 1986 Feb 1;163(2):315-33.

Rosenfeld G. Corante pancrômico para hematologia e citologia clínica. Nova combinação dos componentes do May-Grünwald e do Giemsa num só corante de emprego rápido. Mem Inst Butantan. 1947; 20: 329-334.

Rubartelli A, Poggi A, Zocchi MR. The selective engulfment of apoptotic bodies by dendritic cells is mediated by the alpha(v)beta3 integrin and requires intracellular and extracellular calcium. Eur J Immunol. 1997 Aug;27(8):1893-900.

Sadasivan B, Lehner PJ, Ortmann B, Spies T, Cresswell P.Roles for calreticulin and a novel glycoprotein, tapasin, in the interaction of MHC class I molecules with TAP. Immunity. 1996 Aug;5(2):103-14.

Sallusto F, Lanzavecchia A. Efficient presentation of soluble antigen by cultured human dendritic cells is maintained by granulocyte/macrophage colony-stimulating factor plus interleukin 4 and downregulated by tumor necrosis factor alpha. J Exp Med. 1994 Apr 1;179(4):1109-18.

Sallusto F, Cella M, Danieli C, Lanzavecchia A. Dendritic cells use macropinocytosis and the mannose receptor to concentrate macromolecules in the major histocompatibility complex class II compartment: downregulation by cytokines and bacterial products. J Exp Med. 1995 Aug 1;182(2):389-400.

Salven P, Orpana A, Joensuu H. Leukocytes and platelets of patients with cancer contain high levels of vascular endothelial growth factor. Clin Cancer Res. 1999 Mar;5(3):48791.

Salton JW, Inoue K, Perrotte P, El-Naggar AK, Swanson DA, Fidler IJ, Dinney CP. Expression levels of genes that regulate metastasis and angiogenesis correlate with advanced pathological stage of renal cell carcinoma. Am J Pathol. 2001 Feb;158(2):73543. 
Sawano A, Iwai S, Sakurai Y, Ito M, Shitara K, Nakahata T, Shibuya M. Flt-1, vascular endothelial growth factor receptor 1 , is a novel cell surface marker for the lineage of monocyte-macrophages in humans. Blood. 2001 Feb 1;97(3):785-91.

Senger DR, Connolly DT, Van de Water L, Feder J, Dvorak HF. Purification and NH2terminal amino acid sequence of guinea pig tumor-secreted vascular permeability factor. Cancer Res. 1990 Mar 15;50(6):1774-8

Senger DR, Galli SJ, Dvorak AM, Perruzzi CA, Harvey VS, Dvorak HF. Tumor cells secrete a vascular permeability factor that promotes accumulation of ascites fluid. Science. 1983 Feb 25;219(4587):983-5.

Shen H, Clauss M, Ryan J, Schmidt AM, Tijburg P, Borden L, Connolly D, Stern D, Kao J. Characterization of vascular permeability factor/vascular endothelial growth factor receptors on mononuclear phagocytes. Blood. 1993; 81:2767-73

Shibuya M, Claesson-Welsh L. Signal transduction by VEGF receptors in regulation of angiogenesis and lymphangiogenesis. Exp Cell Res. 2006 Mar 10;312(5):549-60.

Specht JM, Wang G, Do MT, Lam JS, Royal RE, Reeves ME, Rosenberg SA, Hwu P. Dendritic cells retrovirally transduced with a model antigen gene are therapeutically effective against established pulmonary metastases. J Exp Med. 1997 Oct 20;186(8):1213-21.

Song W, Kong HL, Carpenter H, Torii H, Granstein R, Rafii S, Moore MA, Crystal RG. Dendritic cells genetically modified with an adenovirus vector encoding the cDNA for a model antigen induce protective and therapeutic antitumor immunity. J Exp Med. 1997 Oct 20;186(8):1247-56.

Sozzani S, Sallusto F, Luini W, Zhou D, Piemonti L, Allavena P, Van Damme J, Valitutti S, Lanzavecchia A, Mantovani A. Migration of dendritic cells in response to formyl peptides, C5a, and a distinct set of chemokines. J Immunol. 1995 Oct 1;155(7):3292-5.

Sozzani S, Luini W, Borsatti A, Polentarutti N, Zhou D, Piemonti L, D'Amico G, Power CA, Wells TN, Gobbi M, Allavena P, Mantovani A. Receptor expression and responsiveness of human dendritic cells to a defined set of $\mathrm{CC}$ and $\mathrm{CXC}$ chemokines. $\mathrm{J}$ Immunol. 1997 Aug 15;159(4):1993-2000.

Sozzani S, Luini W, Bianchi G, Allavena P, Wells TN, Napolitano M, Bernardini G, Vecchi A, D'Ambrosio D, Mazzeo D, Sinigaglia F, Santoni A, Maggi E, Romagnani S, Mantovani A. The viral chemokine macrophage inflammatory protein-II is a selective Th2 chemoattractant. Blood. 1998 Dec 1;92(11):4036-9.

Starling GC, McLellan AD, Egner W, Sorg RV, Fawcett J, Simmons DL, Hart DN. Intercellular adhesion molecule-3 is the predominant co-stimulatory ligand for leukocyte 
function antigen-1 on human blood dendritic cells. Eur J Immunol. 1995 Sep;25(9):252832.

Steinman RM. The dendritic cell system and its role in immunogenicity. Annu Rev Immunol. 1991;9:271-96.

Steinman RM. Some interfaces of dendritic cell biology. APMIS. 2003 Jul-Aug; 111(78):675-97.

Steinman RM, Banchereau J. Taking dendritic cells into medicine. Nature. 2007 Sep 27;449(7161):419-26.

Steinman RM, Cohn ZA. Identification of a novel cell type in peripheral lymphoid organs of mice. Morphology, quantitation, tissue distribution. J Exp Med. 1973 May 1;137 (5): 1142-62.

Steinman RM, Hawiger D, Nussenzweig MC Tolerogenic dendritic cells. Annu Rev Immunol. 2003;21:685-711. Epub 2001 Dec 19.

Strunk D, Egger C, Leitner G, Hanau D, Stingl G. A skin homing molecule defines the langerhans cell progenitor in human peripheral blood. J Exp Med. 1997 Mar 17;185(6):1131-6.

Svensson M, Stockinger B, Wick MJ. Bone marrow-derived dendritic cells can process bacteria for MHC-I and MHC-II presentation to T cells. J Immunol. 1997 May $1 ; 158(9): 4229-36$.

Tabone MD, Landman-Parker J, Arcil B, Coudert MC, Gerota I, Benbunan M, Leverger G, Dosquet C. Are basic fibroblast growth factor and vascular endothelial growth factor prognostic indicators in pediatric patients with malignant solid tumors? Clin Cancer Res. 2001 Mar;7(3):538-43.

Tang A, Amagai M, Granger LG, Stanley JR, Udey MC. Adhesion of epidermal Langerhans cells to keratinocytes mediated by E-cadherin. Nature. 1993 Jan 7;361(6407):82-5.

Tsuji S, Matsumoto M, Takeuchi O, Akira S, Azuma I, Hayashi A, Toyoshima K, Seya T. Maturation of human dendritic cells by cell wall skeleton of Mycobacterium bovis bacillus Calmette-Guérin: involvement of toll-like receptors. Infect Immun. 2000;68(12):6883-90.

Terman BI, Jani-Sait S, Carrion ME, Shows TB. The KDR gene maps to human chromosome 4q31.2----q32, a locus which is distinct from locations for other type III growth factor receptor tyrosine kinases. Cytogenet Cell Genet. 1992;60 (3-4):214-5. 
Toi M, Hoshina S, Takayanagi T, Tominaga T. Association of vascular endothelial growth factor expression with tumor angiogenesis and with early relapse in primary breast cancer. Jpn J Cancer Res. 1994 Oct;85(10):1045-9.

Troy A, Davidson P, Atkinson C, Hart D. Phenotypic characterization of the dendritic cell infiltrate in prostate cancer. J Urol. 1998 (A) Jul;160(1):214-9.

Troy A, Summers KL, Davidson PJ, Atkinson CH, Hart DN. Minimal recruitment and activation of dendritic cells within renal cell carcinoma. Clin Cancer Res. 1998 (B) Mar;4(3):585-93.

Winzler C, Rovere P, Rescigno M, Granucci F, Penna G, Adorini L, Zimmermann VS, Davoust J, Ricciardi-Castagnoli P. Maturation stages of mouse dendritic cells in growth factor-dependent long-term cultures. J Exp Med. 1997 Jan 20;185(2):317-28.

Vêncio RZ, Koide T. HTself: self-self based statistical test for low replication microarray studies. DNA Res. 2005;12(3):211-4.

Verdijk P, van Veelen PA, de Ru AH, Hensbergen PJ, Mizuno K, Koerten HK, Koning F, Tensen CP, Mommaas AM. Morphological changes during dendritic cell maturation correlate with cofilin activation and translocation to the cell membrane. Eur J Immunol, 2004; 34(1):156-64.

Zhang L, Conejo-Garcia JR, Katsaros D, Gimotty PA, Massobrio M, Regnani G, Makrigiannakis A, Gray H, Schlienger K, Liebman MN, Rubin SC, Coukos G. Intratumoral T cells, recurrence, and survival in epithelial ovarian cancer. $\mathrm{N}$ Engl J Med. 2003 Jan 16;348(3):203-13.

Zhao Q, Egashira K, Inoue S, Usui M, Kitamoto S, Ni W, Ishibashi M, Hiasa Ki K, Ichiki T, Shibuya M, Takeshita A. Vascular endothelial growth factor is necessary in the development of arteriosclerosis by recruiting/activating monocytes in a rat model of longterm inhibition of nitric oxide synthesis. Circulation. 2002 Mar 5;105(9):1110-5.

Zhou LJ, Tedder TF. Human blood dendritic cells selectively express CD83, a member of the immunoglobulin superfamily. J Immun. 1995a; 154: 3821-3835.

Zhou LJ, Tedder TF.A distinct pattern of cytokine gene expression by human CD83+ blood dendritic cells. Blood. 1995b; 86(9):3295-301.

Zou W, Machelon V, Coulomb-L'Hermin A, Borvak J, Nome F, Isaeva T, Wei S, Krzysiek R, Durand-Gasselin I, Gordon A, Pustilnik T, Curiel DT, Galanaud P, Capron F, Emilie D, Curiel TJ. Stromal-derived factor-1 in human tumors recruits and alters the function of plasmacytoid precursor dendritic cells. Nat Med. 2001 Dec;7(12):1339-46. 
Zou W. Immunosuppressive networks in the tumor environment and their therapeutic relevance. Nat Rev Cancer. 2005; 5:263-74.

Zhu KJ, Shen QY, Cheng H, Mao XH, Lao LM, Hao GL. Triptolide affects the differentiation, maturation and function of human dendritic cells. Int Immunopharmacol. 2005 Aug; 5(9):1415-26. 